\title{
WYBRANE ASPEKTY KURCZENIA SIĘ MIAST W POLSCE
}

\author{
SELECTED ASPECTS OF THE SHRINKING OF CITIES IN POLAND
}

\author{
Nr DOI: $10.25167 / \mathrm{sm} 2018.029 .04 \quad$ s. $61-75$
}

\begin{abstract}
ABSTRAKT: Jednym z najbardziej istotnych problemów współczesnego rozwoju wielu miast jest proces ich kurczenia się (shrinking cities). Kurczenie się miast jest zjawiskiem zróżnicowanym i złożonym ze względu na jego wieloaspektowy i wielowymiarowy charakter. Skala tego zjawiska niesie ze sobą wiele negatywnych skutków, widocznych w kontekście zmian demograficznych, społecznych, gospodarczych i przestrzennych.

Przedmiotem opracowania jest zagadnienie kurczenia się miast w Polsce. W opracowaniu dokonano analizy wybranych aspektów demograficznych, gospodarczych i przestrzennych miast liczących powyżej 100 tys. mieszkańców. Badaniem objęto okres 2000-2015.
\end{abstract}

SŁOWA KLUCZOWE: kurczenie się miast, aspekt demograficzny, gospodarczy i przestrzenny kurczenia się miast, miasta Polski

ABSTRACT: One of the most important problems of the present development of many cities is the process of their shrinking. Shrinkage is a complex and varied phenomenon because of its multi-dimensional, multiscalar and multi-temporal character. The dynamics and range of this phenomenon bring a lot of negative consequences. The effects of city shrinkage are visible in cities in the context of social and demographic models, economic processes or spatial changes.

The main issue in the paper is the shrinking of the cities in Poland. The paper presents selected demographic, economic and spatial aspects of cities with over 100,000 inhabitants. The study covered the period of 2000-2015.

KEY WORDS: shrinking of cities, aspects of demographic, economics and space of shrinking of cities, Polish cities

\section{Wprowadzenie}

Kurczenie się miast jest jednym z ważniejszych zjawisk społecznych, gospodarczych i przestrzennych, które zachodzą na obszarach miejskich. Problem ten dotyczy wielu ośrodków na świecie. Najbardziej znanym przykładem jest Detroit w Stanach Zjednoczonych. Regres miasta był skutkiem kryzysu w branży motoryzacyjnej stanowiącej podstawę jego gospodarki i jednocześnie główne miejsce zatrudnienia mieszkańców

\footnotetext{
* Uniwersytet Ekonomiczny w Krakowie, Katedra Gospodarki Regionalnej, e-mail: musialm@uek.krakow.pl.
} 
(Kowalewski 2013, s. 110-113). Można wskazać również inne miasta amerykańskie, które dotknięte zostały - podobnie jak Detroit - procesami depopulacji. Wśród nich można wymienić m.in.: Baltimore $\mathrm{z}$ depopulacją związaną z upadkiem tamtejszego portu, Flint, którego niekorzystna sytuacja demograficzna była wynikiem upadku przemysłu motoryzacyjnego, ponadto St. Louis, Memphis czy Cleveland. Podobne problemy dotknęły wiele miast w Europie, m.in. w Niemczech (Lipsk-Halle), Wielkiej Brytanii (Liverpool), Czechach (Ostrawa), Włoszech (Genua), Hiszpanii (Bilbao), Francji (Saint-Etienne) czy Rumunii (Timiszoara). Proces kurczenia się miast zachodzi również w Polsce.

Problem należy rozpatrywać jako układ specyficznych determinant warunkujących ten proces oraz jego wieloaspektowe konsekwencje. Największy wpływ na proces kurczenia się miast mają te determinanty, które związane są z transformacją ekonomiczną i restrukturyzacją przemysłu oraz z konsekwencjami drugiego przejścia demograficznego. Zjawisko kurczenia się odnosi się zatem do ośrodków miejskich, w których obserwuje się straty ludności, spadek zatrudnienia i/lub przedłużający się kryzys gospodarczy. Ponadto miasta dotknięte tym procesem charakteryzują się ujemnym przyrostem naturalnym i saldem migracji oraz transformacją struktury gospodarki miejskiej.

Celem artykułu jest przedstawienie problematyki kurczących się miast w Polsce. Przeprowadzona analiza ma pokazać, jak kształtuje się ten proces w wymiarze demograficznym, gospodarczym i przestrzennym. W niniejszym artykule obszarem badań objęto miasta liczące powyżej 100 tys. mieszkańców. Analiza wybranych wskaźników na przykładzie tych miast pozwoli zobrazować zjawisko i równocześnie dostrzec skalę całego procesu. Ogólnej charakterystyki tego procesu dokonano, uwzględniając jedynie wybrane jego aspekty. Zakres czasowy analizy obejmuje lata 2000-2015.

\section{Kurczenie się miast - przyczyny i skutki}

W literaturze przedmiotu można wskazać dwa podejścia definiowania procesu kurczenia się miast. W pierwszym, tzw. tradycyjnym, ujęciu uwzględnia się postępującą depopulację powiązaną z pogarszającą się sytuacją ekonomiczną miasta. Drugi aspekt traktuje kurczenie się miast jako proces przekształceń społecznych, ekonomicznych i przestrzennych, który zachodzi w warunkach stałego ubytku liczby ludności (Zborowski, Soja, Łobodziński 2012, s. 7-11).

Międzynarodowa Sieć Badawcza ds. Kurczących się Miast (Shrinking Cities International Reaserch Network - SCIRN) definiuje miasto kurczące się jako obszar miejski charakteryzujący się dużą gęstością zaludnienia, zamieszkiwany przez nie mniej niż 10 tys. mieszkańców. W mieście takim odnotowuje się spadek liczby ludności trwający powyżej 5 lat, o nasileniu wyższym niż 0,15\% rocznie. Kurczące się miasto to również taki obszar miejski, w którym zmiany ekonomiczne charakteryzują się kryzysem strukturalnym zaistniałym w wyniku zachodzącego procesu transformacji gospodarczej (Stryjakiewicz et al. 2014, s. 11-12). 
Podstawowymi wskaźnikami kurczenia się miast są czynniki społeczno-demograficzne. Ponadto pojawiają się różnego rodzaju problemy o charakterze gospodarczym i przestrzennym, które pozostają z nim w związku przyczynowo-skutkowym.

Przyczyn kurczenia się miast jest wiele i są one różnorodne. Ważną kwestią jest kryzys ich lokalnej gospodarki (Haase 2013, s. 32). Zlokalizowane na terenach tych miast zakłady przemysłowe po 1990 r. upadły lub przechodziły poważny kryzys, czego efektem był wzrost poziomu bezrobocia i w konsekwencji odpływ ludności. Otwarcie miast na procesy globalizacji, upadek tradycyjnych gałęzi i branż gospodarki, likwidacja zakładów przemysłowych oraz migracja zarówno wewnętrzna, jak i zewnętrzna wpłynęły na zmianę funkcji ekonomicznej miast, zmianę ich dotychczasowych struktur funkcjonalno-przestrzennych, społecznych i demograficznych - a zatem na procesy w nich zachodzące. Szczególnie trudne dostosowanie do nowych warunków rynkowych miało miejsce w miastach, które nie miały zróżnicowanych funkcji, zaś dominującą gałęzią ich gospodarki był przemysł. Miasta, które nie zdołały rozwinąć nowoczesnego przemysłu bądź przekształcić się w nowoczesne ośrodki usługowe w czasie przemian, obecnie przeżywają kryzys. Skutkiem tych zmian jest zła sytuacja na ich rynku pracy i związane z nią: ubóstwo, segregacja i marginalizacja społeczna. Sytuacja ta doprowadziła do masowych migracji mieszkańców tych miast do ośrodków miejskich, które oferują miejsca pracy i lepsze warunki życia (Stryjakiewicz et al. 2014, s. 80; Musiał-Malago' 2016, s. 92-94).

Proces kurczenia się miast jest efektem globalnych przemian gospodarczych, deindustrializacji, suburbanizacji i czynników demograficznych występujących łącznie, które w konsekwencji mogą doprowadzić do zjawiska upadania miasta.

W badaniach na temat procesu kurczenia się miast istotne jest rozróżnienie kurczenia się rzeczywistego od pozornego. Rzeczywiste kurczenie się miast oznacza, iż depopulacji w danym czasie podlega równocześnie zarówno miasto, jak i jego otoczenie. Miasto charakteryzuje się wysoką stopą bezrobocia oraz odpływem ludności, zwłaszcza młodej i wykształconej. Drugi aspekt zjawiska ma miejsce wówczas, gdy miasto traci mieszkańców w swoich granicach administracyjnych na rzecz jednostek znajdujących się w ich otoczeniu, powiązanych z miastem funkcjonalnie. Miasto traci więc mieszkańców na skutek procesu suburbanizacji. Należy jednak zaznaczyć, że wyludnianie się pozorne miasta nie oznacza regresu ekonomicznego tego ośrodka. Duże miasta, które podlegają silnym procesom suburbanizacji, mogą nadal pełnić rolę ważnych ośrodków rozwoju i wzrostu gospodarczego.

T. Stryjakiewicz dzieli miasta kurczące się, ze względu na kierunki i natężenie zmian liczby ludności, na trzy rodzaje, a mianowicie:

- trwale kurczące się (długookresowo) - cechujące się spadkiem ludności w stosunku rocznym wynoszącym ponad 0,15\% w dłuższym okresie czasu (np. 10 lat i więcej);

- czasowo kurczące się (krótkookresowo) - charakteryzujące się spadkiem liczby mieszkańców w okresie np. krótszym niż 10 lat o ponad 0,15\%, w których jednocześnie odnotowuje się przynajmniej jedno pięciolecie stabilizacji (zmiany na poziomie od $-0,15 \%$ do $+0,15 \%)$ lub nawet wzrostu wielkości populacji (>0,15\%); 
- epizodycznie kurczące się (w niektórych latach) - w których łączna liczba mieszkańców w dłuższym okresie czasu zmalała nieznacznie (do 0,15\% w ujęciu rocznym), przy czym odnotowuje się przynajmniej jeden pięcioletni okres spadku liczby ludności (Stryjakiewicz et al. 2014, s. 11).

Spadek populacji miejskiej jest zarówno efektem, jak i przyczyną pogłębiania się procesu kurczenia się miast. Wyjaśnieniem teoretycznym tego zjawiska może być teoria kumulatywnej przyczynowości G. Myrdala ${ }^{1}$. Proces ten można określić jako względny lub bezwzględny. Względne kurczenie się miasta zachodzi wówczas, gdy odpływ ludności następuje z miasta do gmin położonych w jego otoczeniu, zaś bezwzględne charakteryzuje się odpływem mieszkańców z miasta oraz jego otoczenia suburbialnego (Jaroszewska 2013, s. 59; Musiał-Malago' 2017, s. 72-73; Stryjakiewicz et al. 2014, s. 13-14).

Spadek liczby mieszkańców miasta wywołuje poważne konsekwencje, m.in. społeczne, gospodarcze i przestrzenne. Demograficzne konsekwencje procesu kurczenia się miast wyrażają się ubytkiem liczby mieszkańców miasta na skutek malejącego przyrostu naturalnego i migracji ludności. W wyniku spadku potencjału ludnościowego zachodzą niekorzystne zmiany w strukturze wiekowej ludności. Następuje spadek liczby mieszkańców w wieku przedprodukcyjnym i stały wzrost liczby osób w wieku emerytalnym. Depopulacja i zwiększenie się współczynnika obciążenia demograficznego wpływa niekorzystnie na procesy ekonomiczne zachodzące w miastach. Efektem tych zmian jest ubożenie społeczeństwa i nadmierne obciążenie systemu emerytalnego. Starzenie się społeczeństwa zwiększa zapotrzebowanie na usługi medyczne i pomoc społeczną, co z kolei wpływa na wzrost wydatków jednostek samorządu terytorialnego. Spadek liczby ludności prowadzi do obniżenia się gęstości zaludnienia, co z kolei skutkuje wzrostem jednostkowych kosztów funkcjonowania miast. Szczególnie ma to wyraz we wzroście utrzymania i rozwoju infrastruktury oraz w obniżeniu wskaźników jej wykorzystania. Nadmierne obciążenie pozostałych mieszkańców kosztami utrzymania istniejącej infrastruktury technicznej i społecznej powoduje stopniowe ubożenie, a w konsekwencji upadek miasta. Skutkiem spadku populacji jest również osłabienie podstaw funkcjonowania usług komercyjnych czy obiektów publicznych (Czarnecki 2011, s. 14-17; Musiał-Malago' 2017, s. 73).

W obszarze konsekwencji ekonomicznych można wymienić m.in.: kurczenie się rynku nieruchomości, spadek wartości nieruchomości, niższy popyt na mieszkania, wzrost liczby pustostanów, degradację terenów i obiektów nieużywanych, „perforację” struktur przestrzennych, segregację przestrzenną. Niekorzystne zmiany struktury

1 Według Myrdala każdy system społeczny składa się z dużej liczby warunków powiązanych między sobą przyczynowo. Wynikają z tego wzajemne zależności elementów układu. Zmiana jednego z warunków pociąga za sobą zmiany innych, co z kolei powoduje zmiany w całym układzie (teoria kumulatywnej przyczynowości). Jedną z prób interpretacji procesu kurczenia się jest nawiązanie do wspomnianej teorii, w której zmniejszanie się liczby ludności w miastach - na zasadzie „błędnego koła” - jest zarówno przyczyną, jak i skutkiem tego procesu (za Jaroszewska 2013, s. 59). 
demograficznej powodują spowolnienie rozwoju gospodarczego wynikające m.in. ze zmniejszenia się zasobów siły roboczej i spadku liczby podmiotów gospodarczych. Odpływ ludności w wieku produkcyjnym i przedprodukcyjnym z miast jest niekorzystny ze względu na niższy potencjał siły roboczej, co powoduje, iż spada ich atrakcyjność inwestycyjna. Skutki zjawiska kurczenia się miast wpływają również niekorzystnie na stan finansów samorządów miejskich. Sytuacja dochodowa miast o charakterze wyludniającym się ulega pogorszeniu. Znajduje to odzwierciedlenie m.in. w spadku dochodów miast z podatków płaconych przez mieszkańców (PIT, podatki lokalne). Baza podatkowa zmniejsza się również na skutek odpływu firm i spadku podatków od prowadzonej działalności gospodarczej (Jopek 2015, s. 139-144; Musiał-Malago' 2015, s. 139-144).

Zmiany wynikające z depopulacji prowadzą do zmian w przestrzeni miejskiej. Ich konsekwencją jest ograniczenie nowych inwestycji mieszkaniowych i usługowych, renaturalizacji opuszczonych terenów zurbanizowanych, zmniejszenie liczby usług, miejsc pracy i spowolnienie ogólnego tempa rozwoju gospodarczego. Ponadto w wielu miastach obserwuje się wzrost liczby terenów zdegradowanych. Stan techniczny tych terenów nie pozwala na ich użytkowanie, zaś brak popytu rynkowego powoduje, iż nie są na nich prowadzone prace remontowe (Jopek 2015, s. 152-154). Wzrost liczby pustostanów oraz terenów i obiektów nieużywanych wpływa na spadek wartości nieruchomości oraz osłabienie zainteresowania lokowaniem nowych inwestycji, co w konsekwencji może prowadzić do perforacji struktur przestrzennych.

Kurczenie się miast jest zjawiskiem zróżnicowanym i złożonym, bowiem różne są jego przyczyny, konsekwencje i kontekst przestrzenny. Należy zaznaczyć, iż w wielu obszarach zurbanizowanych występuje więcej niż jedna przyczyna ubytku mieszkańców.

\section{Analiza procesu kurczenia się miast w świetle wybranych wskaźników}

Analizowana grupa ośrodków skupiających powyżej 100 tys. mieszkańców obejmuje 39 miast. W 2015 r. zamieszkiwały je łącznie 10822952 osoby, tj. 47,7\% ludności miast i 28,2\% populacji całego kraju. Wśród tych miast można wydzielić 23 ośrodki z przedziału od 100 do 200 tys. mieszkańców i 16 miast przekraczających 200 tys. mieszkańców.

Zgodnie z przyjętą przez SCIRN typologią spośród 39 analizowanych ośrodków 30 można uznać za kurczące się (tabela 1). W 27 ośrodkach miejskich proces kurczenia się miał charakter długotrwały. W pozostałych trzech miastach odnotowano jedno pięciolecie, w którym zmiany liczby ludności wahały się w przedziale od $-0,15 \%$ do $+0,15 \%$ lub odnotowano niewielki wzrost liczby ludności powyżej 0,15\%. Wśród tych miast znalazły się: Gdynia, Koszalin i Tychy (tabela 2).

Badając przemiany zachodzące w miastach, należy zaznaczyć, iż czynnik demograficzny jest jednym z ważniejszych, jakie mają wpływ na ich życie społeczno-gospodarcze. Analizując dane statystyczne od 2000 r., zauważa się, iż zdecydowana większość miast się wyludnia. Spośród wszystkich 39 miast liczących powyżej 100 tys. 
Miasta kurczące się, stabilne i rosnące - próba klasyfikacji

\begin{tabular}{|c|c|c|c|}
\hline \multirow{2}{*}{$\begin{array}{c}\text { Grupa } \\
\text { wielkościowa } \\
\text { miast } \\
\text { (wg liczby } \\
\text { mieszkańców) }\end{array}$} & \multicolumn{3}{|c|}{ Miasta powyżej 100 tys. mieszkańców } \\
\hline & $\begin{array}{l}\text { Kurczące się (regresywne) - } \\
\text { cechują się ubytkiem ludności } \\
\text { w stosunku rocznym wynoszą- } \\
\text { cym ponad 0,15\% w badanym } \\
\text { okresie. }\end{array}$ & $\begin{array}{l}\text { Stabilne (stagnujące) } \\
\text { - cechują się zmianą } \\
\text { liczby ludności zawie- } \\
\text { rającą się w przedziale } \\
\text { od -0,15\% do } 0,15 \% \\
\text { w stosunku rocznym } \\
\text { w badanym okresie. }\end{array}$ & $\begin{array}{l}\text { Rosnące (progresywne) } \\
\text { - cechują się wzrostem } \\
\text { liczby ludności wyno- } \\
\text { szącym ponad 0,15\% } \\
\text { w stosunku rocznym } \\
\text { w badanym okresie. }\end{array}$ \\
\hline $100000-199999$ & $\begin{array}{l}\text { Bielsko-Biała, Bytom, Cho- } \\
\text { rzów, Dąbrowa Górnicza, } \\
\text { Elbląg, Gliwice, Kalisz, Kielce, } \\
\text { Koszalin, Legnica, Opole, } \\
\text { Płock, Ruda Ŝląska, Rybnik, } \\
\text { Tarnów, Tychy, Wałbrzych, } \\
\text { Włocławek, Zabrze }\end{array}$ & $\begin{array}{l}\text { Zielona Góra, Gorzów } \\
\text { Wielkopolski, Olsztyn }\end{array}$ & Rzeszów \\
\hline $200000-299999$ & $\begin{array}{l}\text { Czestochowa, Gdynia, Katowi- } \\
\text { ce, Radom, Sosnowiec, Toruń }\end{array}$ & Białystok & \\
\hline $300000-499999$ & Bydgoszcz, Lublin, Szczecin & Gdańsk & \\
\hline 500000 i więcej & Łódź, Poznań & Kraków, Wrocław & Warszawa \\
\hline
\end{tabular}

Źródło: opracowanie własne na podstawie danych GUS, BDL (obliczenia obejmują lata 2000-2015).

Rodzaje miast kurczących się ze względu na kierunki i natężenie zmian liczby ludności (w latach 2000-2015)

\begin{tabular}{|c|c|c|}
\hline \multicolumn{3}{|c|}{ Miasta powyżej 100 tys. mieszkańców } \\
\hline $\begin{array}{l}\text { Trwale kurczące się (długookre- } \\
\text { sowo) - cechują się spadkiem } \\
\text { populacji wynoszącym ponad } \\
\text { 0,15\% w ujęciu rocznym w całym } \\
\text { analizowanym okresie. }\end{array}$ & $\begin{array}{l}\text { Czasowo kurczące się (krótko- } \\
\text { okresowo) - liczba mieszkań- } \\
\text { ców w analizowanym okresie } \\
\text { zmalała (o ponad 0,15\%), przy } \\
\text { czym odnotowano przynajmniej } \\
\text { jedno pięciolecie stabilizacji } \\
\text { (zmiany na poziomie od -0,15\% } \\
\text { do +0,15\%) lub nawet wzrostu } \\
\text { wielkości populacji (>0,15\%). }\end{array}$ & $\begin{array}{l}\text { Epizodycznie kurczące się - } \\
\text { łączna liczba mieszkańców } \\
\text { w badanych latach nie zmalała } \\
\text { o ponad 0,15\% w ujęciu rocz- } \\
\text { nym, jednak wystąpił przynaj- } \\
\text { mniej jeden pięcioletni okres } \\
\text { spadku wielkości populacji. }\end{array}$ \\
\hline $\begin{array}{l}\text { Bielsko-Biała, Bydgoszcz, Bytom, } \\
\text { Chorzów, Częstochowa, Dąbro- } \\
\text { wa Górnicza, Elbląg, Gliwice, } \\
\text { Kalisz, Katowice, Kielce, Legni- } \\
\text { ca, Lublin, Łódź, Opole, Płock, } \\
\text { Poznań, Radom, Ruda Śląska, } \\
\text { Rybnik, Sosnowiec, Szczecin, } \\
\text { Tarnów, Toruń, Wałbrzych, } \\
\text { Włocławek, Zabrze }\end{array}$ & Gdynia, Koszalin, Tychy & - \\
\hline
\end{tabular}

Źródło: opracowanie własne na podstawie danych GUS, BDL (obliczenia obejmują lata 2000-2015). 
mieszkańców tylko w sześciu miał miejsce wzrost liczby ludności, tj. w: Warszawie, Rzeszowie, Zielonej Górze, Białymstoku, Krakowie, Olsztynie. Miasta te nie mają w bliskim sąsiedztwie konkurencyjnych ośrodków, dlatego też stanowią miejsce migracji ludności z innych obszarów. Są to rozwijające się ośrodki, atrakcyjne pod względem rynku pracy, co powoduje stały wzrost liczby ich mieszkańców. Niektóre z nich mają korzystną sytuację demograficzną na wskutek przeprowadzonych zmian administracyjnych i poszerzenia granic miasta ${ }^{2}$.

Wśród miast kurczących się najwięcej mieszkańców straciła Łódź - 97 tys. Na kolejnej pozycji znalazł się Poznań, w którym obserwuje się spadek liczby mieszkańców głównie z powodu zachodzącego procesu suburbanizacji. Znaczny ubytek ludności odnotowuje się w miastach konurbacji katowickiej. Największy spadek liczebności odnotowano w: Katowicach (31 tys.), Sosnowcu (27 tys.), Bytomiu i Częstochowie (po 25 tys.) (ryc. 1). Utrata potencjału ludnościowego w tych ośrodkach jest bardzo duża, sięga ok. 15\% stanu wyjściowego. Ubytek mieszkańców dotyka w największym stopniu stare ośrodki przemysłowe oraz miasta o dużym natężeniu procesu suburbanizacji.

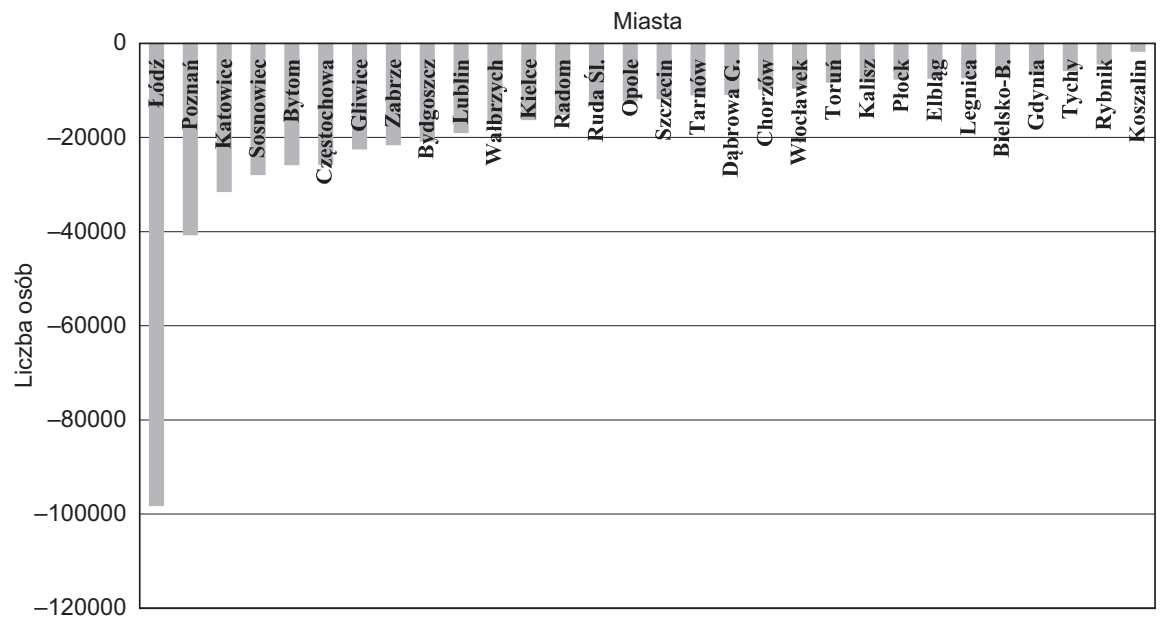

Ryc. 1. Bezwzględny spadek liczby ludności w miastach kurczących się w latach 2000-2015

Źródło: opracowanie własne.

2 Powierzchnia Rzeszowa uległa powiększeniu w wyniku przyłączenia do miasta dotychczasowych obszarów podmiejskich (fragmenty obszaru powiatu rzeszowskiego: gmina Tyczyn i Głogów Małopolski). Korzystna sytuacja demograficzna Białegostoku związana jest z powiększeniem granic miasta na skutek przyłączenia do jego terytorium podmiejskich miejscowości (w 2002 r. miejscowość Zawady, zaś w 2006 r. miejscowości gminy Zabłudów, tj. Dojlidy Górne i kolonia, Zagórki i kolonia Halickie). Granice Gorzowa Wielkopolskiego także zostały poszerzone z dniem 1 stycznia 2002 r. poprzez włączenie do powiatu grodzkiego części obszarów wsi sąsiedniej Santocko z gminy Kłodawa w powiecie gorzowskim. Również Zielona Góra powiększyła swoje terytorium w wyniku przyłączenia gminy wiejskiej Zielona Góra. Formalnie od stycznia 2015 r. utworzona na jej terenie nowa dzielnica zwana Nowe Miasto funkcjonuje jako część administracyjna miasta Zielona Góra (www.stat.gov.pl). 
Ze zmianą liczby ludności miasta związane są wskaźniki takie jak przyrost naturalny i saldo migracji. Mogą one świadczyć o sytuacji ekonomicznej danego ośrodka miejskiego i o jego atrakcyjności jako miejsca oferującego korzystne warunki do zamieszkania. Zmiany pod względem przyrostu naturalnego ludności różnią się swoim przebiegiem w badanych miastach. W poddanych analizie jednostkach w 2015 r. odnotowano dodatni przyrost naturalny jedynie w czterech miastach kurczących się (Tychy, Lublin, Rybnik i Toruń). Wskaźniki te mieszczą się w przedziale od 0,2 do 0,6. W pozostałych 26 miastach współczynnik przyrostu naturalnego ludności przyjmował wartości ujemne, najwyższe w Wałbrzychu $(-6,7)$ i Łodzi $(-6,3)$. W 10 miastach nastąpił wzrost wartości wskaźnika przyrostu naturalnego, przy czym, jak już wspomniano, w czterech miastach było to przejście od ubytku do przyrostu naturalnego (ryc. 2).

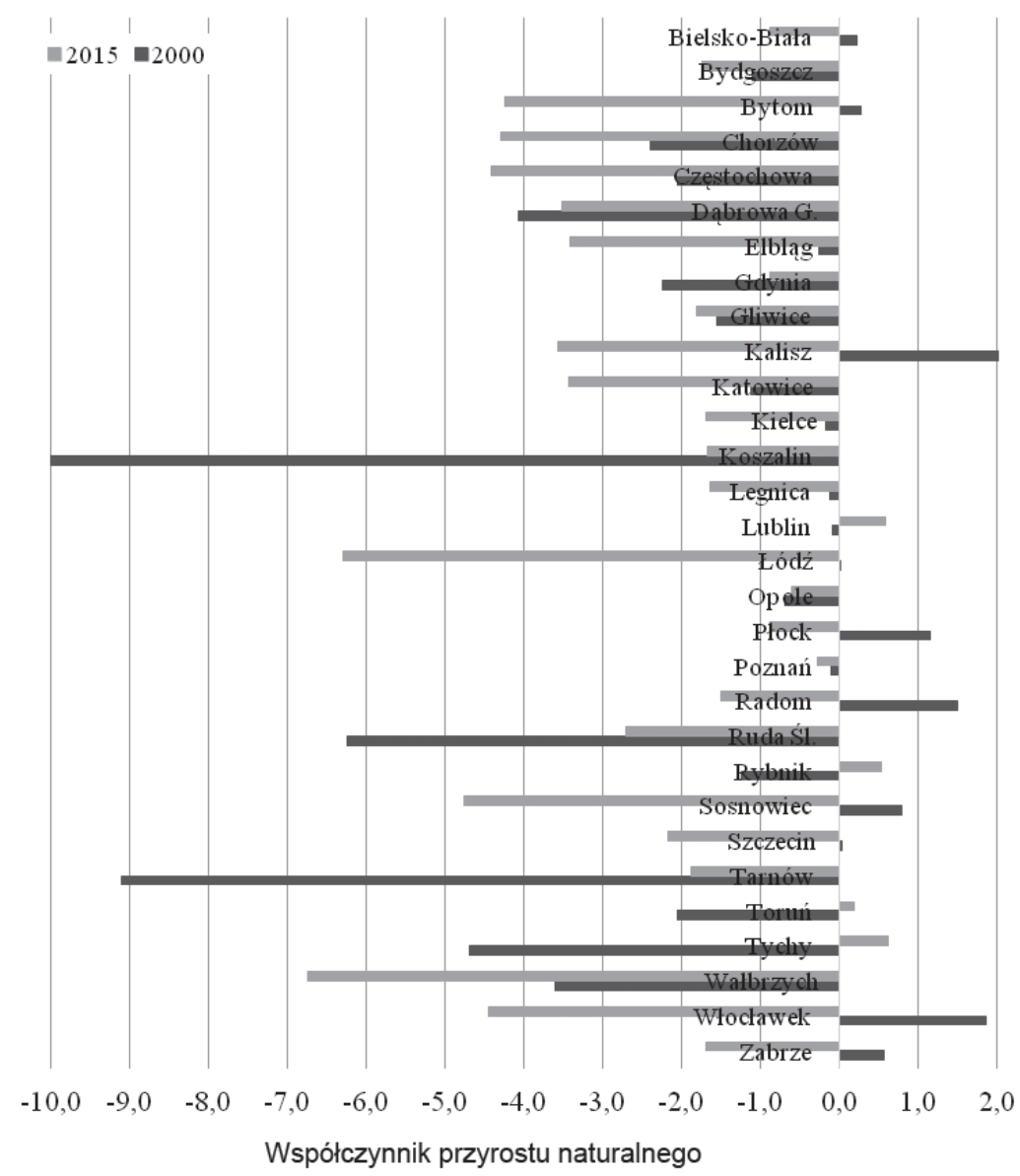

Ryc. 2. Przyrost naturalny na 1000 ludności w miastach kurczących się w latach 2000 i 2015

Źródło: opracowanie własne. 
Istotnym elementem kształtującym sytuację ludnościową miasta są migracje. Do analizy empirycznej procesu kurczenia się miast wykorzystano wskaźnik salda migracji w przeliczeniu na 1000 mieszkańców. W 2015 r. dodatnimi wielkościami salda migracji cechowały się jedynie trzy miasta - Koszalin, Opole i Szczecin. W pozostałych jednostkach odnotowano wartości ujemne. Najwyższy ujemny wskaźnik miał Bytom (-3,8 na 1000 mieszkańców), zaś najniższy Gdynia (-0,2 na 1000 mieszkańców). W latach 2000-2015 w ośmiu badanych ośrodkach (Elbląg, Dąbrowa Górnicza, Poznań, Częstochowa, Płock, Zabrze, Bielsko-Biała, Kalisz) zanotowano spadek salda migracji. W pozostałych miastach odnotowano wzrost tego wskaźnika, przy czym jedynie trzy miasta osiągnęły wartości dodatnie. Dla porównania w 2000 r. miasta te wykazywały ujemne saldo migracji. Duży odpływ ludności z ośrodków miejskich wystąpił zwłaszcza do ich strefy podmiejskiej, która ze względu na aspekty społeczne, ekonomiczne czy środowiskowe stała się atrakcyjna dla ludności miejskiej. Ponadto warto dodać, że w 2015 r. żadne z badanych miast nie wyróżniało się zarówno dodatnim przyrostem naturalnym, jak i dodatnim saldem migracji.

Opis kurczenia się miast za pomocą wskaźników demograficznych nie odzwierciedla wielowymiarowości tego procesu. W celu uzyskania pełniejszego obrazu konieczne jest uwzględnienie wskaźników ekonomicznych i przestrzennych. Rozwój demograficzny i ekonomiczny nie przebiegają w oderwaniu od siebie, zwłaszcza w długim okresie, dlatego też do analizy wzięto pod uwagę wskaźniki z obydwu dziedzin. W badaniach wykorzystane zostały dane dotyczące liczby osób zatrudnionych. W analizowanym okresie poziom zatrudnienia w miastach odznaczał się dużą dynamiką. Do 2000 r. wzrastało zatrudnienie w większości badanych miast. Po 2000 r. zauważalna jest cykliczność rozwoju gospodarki. Wyraża się ona spadkami zatrudnienia w latach 2001-2006 i ponownym jego ożywieniem w okresie od 2007 do 2012 r. W okresie od 2001 do 2005 r. miało miejsce pogorszenie sytuacji na rynku pracy. W rezultacie w większości miast kurczących się liczba zatrudnionych się zmniejszyła. Jedynie w czterech miastach obserwuje się tendencję odwrotną: w Bielsku-Białej, Tychach, Wałbrzychu i Poznaniu. Spadek zatrudnienia był zjawiskiem powszechnym, a w niektórych miastach przybrał znaczne rozmiary, m.in. w: Bytomiu (25\%), Chorzowie (12,4\%), Dąbrowie Górniczej (12,2\%), Rudzie Śląskiej (11,2\%), Koszalinie (10\%). Spadek zatrudnienia nastąpił głównie w miastach liczących 100-200 tys. mieszkańców. Znacznie lepiej koniunktura na rynku pracy przedstawiała się w latach 2006-2012. Zatrudnienie wzrosło w większości miast. Wyjątkiem były: Radom, Gdynia, Bytom, Ruda Śląska, Elbląg. Po 2012 r. w większości miast zatrudnienie utrzymywało się na stabilnym poziomie lub nawet niekiedy wzrastało. Wśród kurczących się miast wzrost zatrudnienia miał miejsce w 16 z nich. Największy wzrost zatrudnienia odnotowano w: Tychach (31,2\%), Bielsku-Białej $(29,4 \%)$, Gliwicach (25,2\%), największy spadek zaś w Bytomiu (-37\%), Rudzie Śląskiej (-20\%), Szczecinie i Tarnowie (po -13\%) (tabela 3).

Sytuacja w kurczących się miastach pod względem stopy bezrobocia była zróżnicowana i wahała się w 2015 r. w przedziale 2,4\% do 18,5\%. Najniższą stopę bezrobocia w 2015 r. osiągnął Poznań (2,4). Najwyższą stopę bezrobocia rejestrowanego w 2015 r. 
Zmiana liczby zatrudnionych w miastach kurczących się w latach 2000-2015

\begin{tabular}{|c|l|}
\hline $\begin{array}{c}\text { Zmiana liczby zatrudnionych } \\
{[\%]}\end{array}$ & \multicolumn{1}{|c|}{ Miasta liczące powyżej 100 tys. mieszkańców } \\
\hline$<-10$ & Bytom, Ruda Śląska, Szczecin, Tarnów, Włocławek, Elbląg \\
\hline Od $-5,1$ do $-10,0$ & Dąbrowa Górnicza, Sosnowiec, Płock, Gdynia, Zabrze, Toruń, Rybnik \\
\hline Od $-5,0$ do 5,0 & $\begin{array}{l}\text { Chorzów, Częstochowa, Kalisz, Bydgoszcz, Wałbrzych, Radom, Kielce, } \\
\text { Katowice }\end{array}$ \\
\hline Od 5,1 do 10,0 & Poznań, Koszalin, Lublin, Łódź, Opole \\
\hline$>10,0$ & Legnica, Gliwice, Bielsko-Biała, Tychy \\
\hline
\end{tabular}

Źródło: opracowanie własne na podstawie danych GUS, BDL (dane nie uwzględniają podmiotów gospodarczych o liczbie pracujących do 9 osób).

odnotowano w Bytomiu, Radomiu i Włocławku (powyżej 16\%). Wysoka stopa bezrobocia utrzymywała się także w: Elblągu (12,9\%), Sosnowcu $(11,4 \%)$, Zabrzu (10,5\%), Wałbrzychu (10,4\%) (ryc. 3).

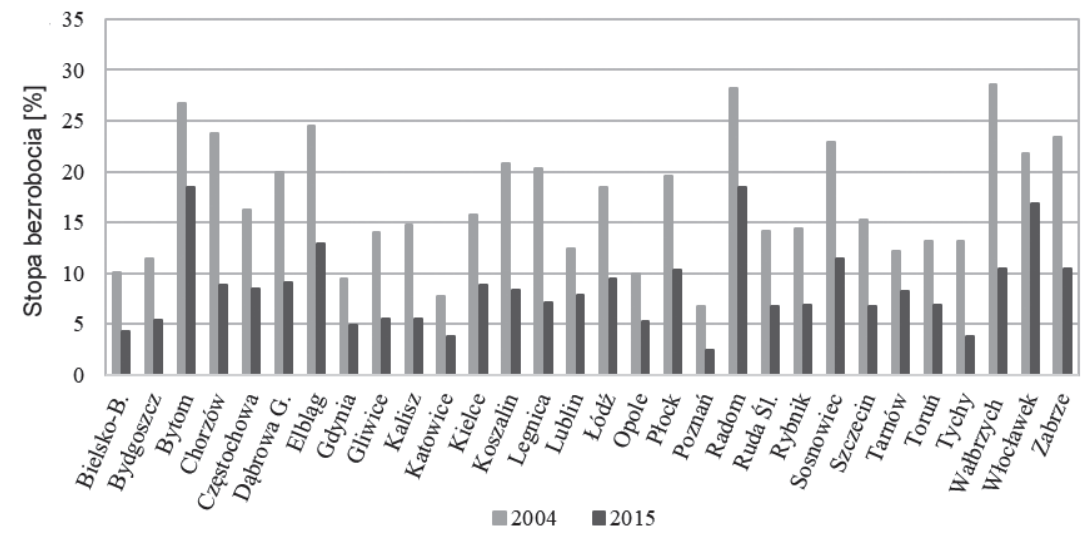

Ryc. 3. Stopa bezrobocia w miastach kurczących się

Źródło: opracowanie własne na podstawie danych GUS, BDL.

W okresie 2004-2015 stopa bezrobocia spadła we wszystkich badanych miastach. Spadek wartości liczbowej tego wskaźnika mieścił się w granicach od 3,9\% (Katowice) do 18,2\% (Wałbrzych). Podsumowując, można stwierdzić, że sytuacja na rynku pracy w większości miast się poprawiła. Należy jednak zaznaczyć, iż pomimo zauważalnej tendencji spadkowej stopa bezrobocia w wielu miastach wciąż jest wysoka. Utrzymujące się bezrobocie prowadzi do trwałego wykluczenia społecznego mieszkańców i związanych z tym patologii życia społecznego i ekonomicznego. Obecnie w miastach prowadzone są działania na rzecz dywersyfikacji struktury gospodarczej. Miasta te stają 
się miejscem lokalizacji kapitału, rozwijają się w nich nowe gałęzie przemysłu i usług. Jednak w wielu przypadkach powstałe nowe podmioty gospodarcze zapewniły jedynie częściową kompensację podaży miejsc pracy. Pomimo iż widoczne są korzystne zmiany w strukturze gospodarczej tych miast, nadal stopa bezrobocia utrzymuje się na wysokim poziomie, co w konsekwencji skutkuje odpływem ludności.

Ostatnim elementem części empirycznej artykułu jest analiza przestrzennego zróżnicowania aktywności budowlanej. Została ona wyrażona za pomocą liczby mieszkań, na których budowę wydane zostały pozwolenia, w przeliczeniu na 10 tys. mieszkańców. Analizując dane z 2015 r., można stwierdzić, że najwyższą aktywnością budowlaną odznaczały się Lublin $(93,5)$ i Szczecin $(79,2)$ (tabela 4). Poziom aktywności budowlanej w miastach był bardzo zróżnicowany w czasie.

Liczba mieszkań z pozwoleniem na budowę w miastach kurczących się

\begin{tabular}{|c|c|c|c|c|}
\hline \multirow{2}{*}{$\begin{array}{c}\text { Liczba mieszkań, } \\
\text { na których budowę } \\
\text { wydano pozwolenie, } \\
\text { na } 1000 \\
\text { mieszkańców }\end{array}$} & \multicolumn{2}{|l|}{ Rok 2005} & \multicolumn{2}{|l|}{ Rok 2015} \\
\hline & miasta & $\begin{array}{l}\text { liczba } \\
\text { miast }\end{array}$ & miasta & $\begin{array}{l}\text { liczba } \\
\text { miast }\end{array}$ \\
\hline$<10,0$ & $\begin{array}{l}\text { Poznań, Częstochowa, Katowi- } \\
\text { ce, Rybnik, Sosnowiec, Lublin, } \\
\text { Dąbrowa Górnicza, Szczecin, } \\
\text { Opole, Tychy, Chorzów }\end{array}$ & 11 & Wałbrzych, Kalisz, Bytom & 3 \\
\hline $10,0-25,0$ & $\begin{array}{l}\text { Wałbrzych, Zabrze, Elbląg, } \\
\text { Bielsko-Biała, Łódź, Radom, } \\
\text { Włocławek, Gliwice, Byd- } \\
\text { goszcz }\end{array}$ & 9 & $\begin{array}{l}\text { Zabrze, Ruda Śląska, Często- } \\
\text { chowa, Włocławek, Tarnów, } \\
\text { Sosnowiec, Legnica, Dąbro- } \\
\text { wa Górnicza, Tychy }\end{array}$ & 9 \\
\hline $25,1-50,0$ & Płock, Bytom, Gdynia, Kalisz & 4 & $\begin{array}{l}\text { Rybnik, Chorzów, Łódź, } \\
\text { Kielce, Płock, Elbląg, Opole, } \\
\text { Bielsko-Biała, Gliwice, Ko- } \\
\text { szalin, Bydgoszcz, Radom }\end{array}$ & 12 \\
\hline $50,1-75,0$ & Toruń, Kielce & 2 & $\begin{array}{l}\text { Katowice, Gdynia, Toruń, } \\
\text { Poznań }\end{array}$ & 4 \\
\hline $75,1-100,0$ & Ruda Śląska & 1 & Szczecin, Lublin & 2 \\
\hline$>100,0$ & Legnica, Koszalin, Tarnów & 3 & - & - \\
\hline
\end{tabular}

Źródło: opracowanie własne na podstawie danych GUS, BDL.

W latach 2001-2006 wyraźnie zmniejszyła się liczba pozwoleń na budowę w niemal wszystkich analizowanych miastach. Z kolei w latach 2007-2011 widać wyraźny ich wzrost, po 2012 r. ponownie niewielki spadek. Biorąc jednak pod uwagę cały badany okres, widoczny jest wzrost liczby mieszkań, na które wydano pozwolenia w 21 miastach (ryc. 4).

Warto zaznaczyć, że w wielu miastach kurczących się, w których starzenie się społeczeństwa ma przyspieszone tempo, po części w związku ze spadkiem populacji 

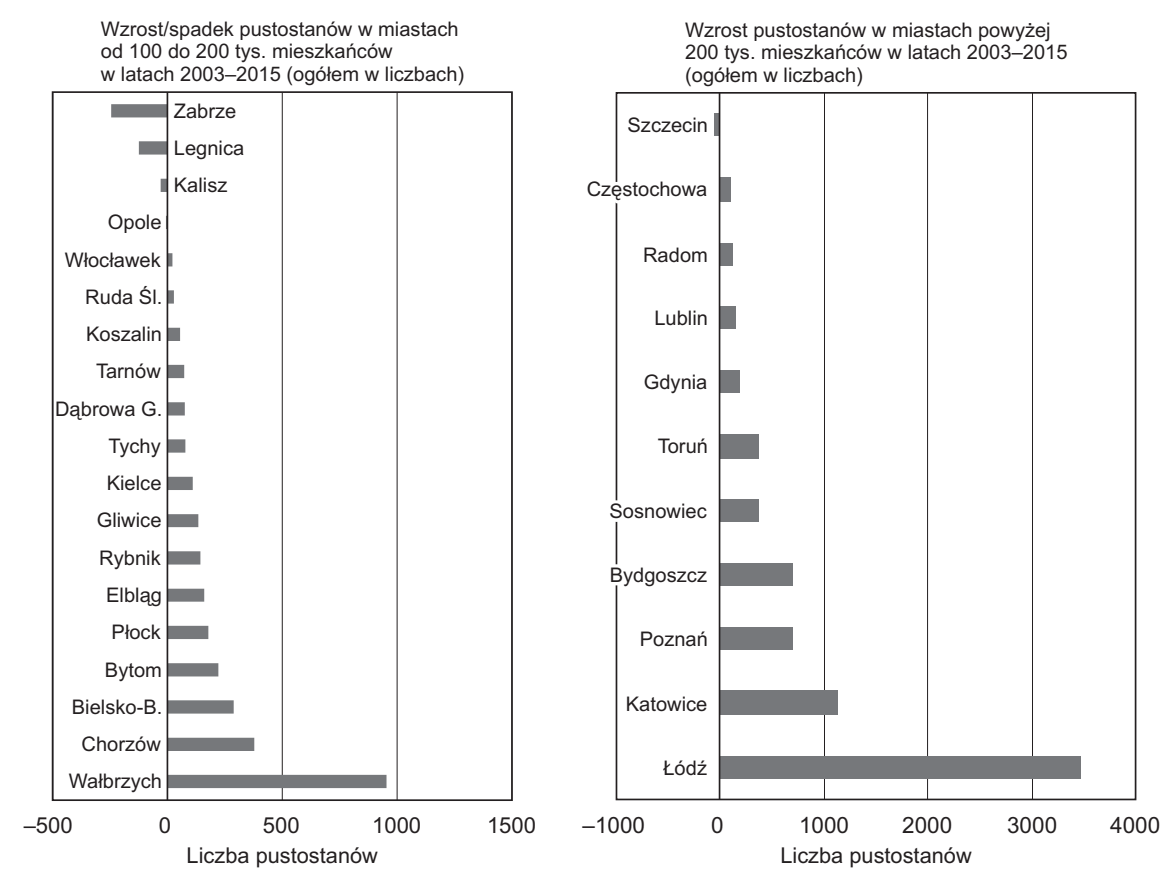

Ryc. 4. Pustostany w miastach kurczących się

Źródło: opracowanie własne na podstawie danych GUS, BDL.

obserwuje się wzrost liczby starych, nieużywanych struktur, takich jak np. pustostany czy tereny zdegradowane.

\section{Polityka miejska w zakresie kurczących się miast}

Proces kurczenia się miast można uważać niewątpliwie za zjawisko negatywne. Przezwyciężenie jego skutków stanowi jedno z ważniejszych wyzwań dla planowania i polityki miejskiej w Polsce w XXI w. W związku z postępującym regresem demograficznym i jego niekorzystnymi prognozami można zaobserwować pewne działania władz zmniejszające negatywne skutki tego procesu ${ }^{3}$. Wciąż jednak nie istnieją konkretne strategie krajowe czy lokalne, które byłyby ukierunkowane na rozwój w warunkach kurczenia się miast. Priorytetem dla objętych tym procesem ośrodków miejskich powinno być stworzenie wizji długookresowego rozwoju w warunkach zachodzącego procesu kurczenia się miasta. Podstawowym czynnikiem warunkującym powodzenie w zapobieganiu i przeciwdziałaniu depopulacji jest komplementarność równocześnie

\footnotetext{
${ }^{3}$ Niektóre miasta/regiony posiadają dokumenty strategiczne zawierające wyzwania związane z wyludnianiem się, jak np.: Plan przeciwdziałania depopulacji w województwie łódzkim 2020 czy Program Specjalnej Strefy Demograficznej w województwie opolskim do 2020 r.
} 
prowadzonych zróżnicowanych działań na wszystkich poziomach władzy publicznej. Przezwyciężenie negatywnych skutków tego procesu wiąże się ze współpracą władz miast i regionów ze społecznością lokalną, dotyczącą całościowych interwencji w strukturę przestrzenną, w tym prawną, funkcjonalną, społeczną (Musiał-Malago' 2016, s. 103-104). Należy podkreślić, że ważnym zadaniem władzy publicznej powinno być właściwe zarządzanie procesem oraz indywidualne podejście do każdego przypadku.

W raportach UE i państw OECD podkreśla się, że depopulacja oraz starzenie się społeczeństwa mają coraz większe znaczenie w ramach różnych obszarów, w tym szczególnie polityki miejskiej. W związku z tym podejmowane są działania, inicjatywy, projekty i strategie dotyczące zmian demograficznych na wszystkich szczeblach - od europejskiego po lokalny. Władze miejskie wielu miast europejskich opracowują strategie nastawione na ciągły ich wzrost. W sprawozdaniu Komisji Europejskiej The impact of European demographic trends on region and urban development (2011) zwrócono uwagę, iż nie ma jednej strategii odnowy miast w Europie. Równocześnie podkreślono, że strategia powinna być zróżnicowana i dostosowana do dynamiki zmian demograficznych zachodzących w mieście, w tym starzenia się populacji (ryc. 5) (Labus 2015, s. 1-2).

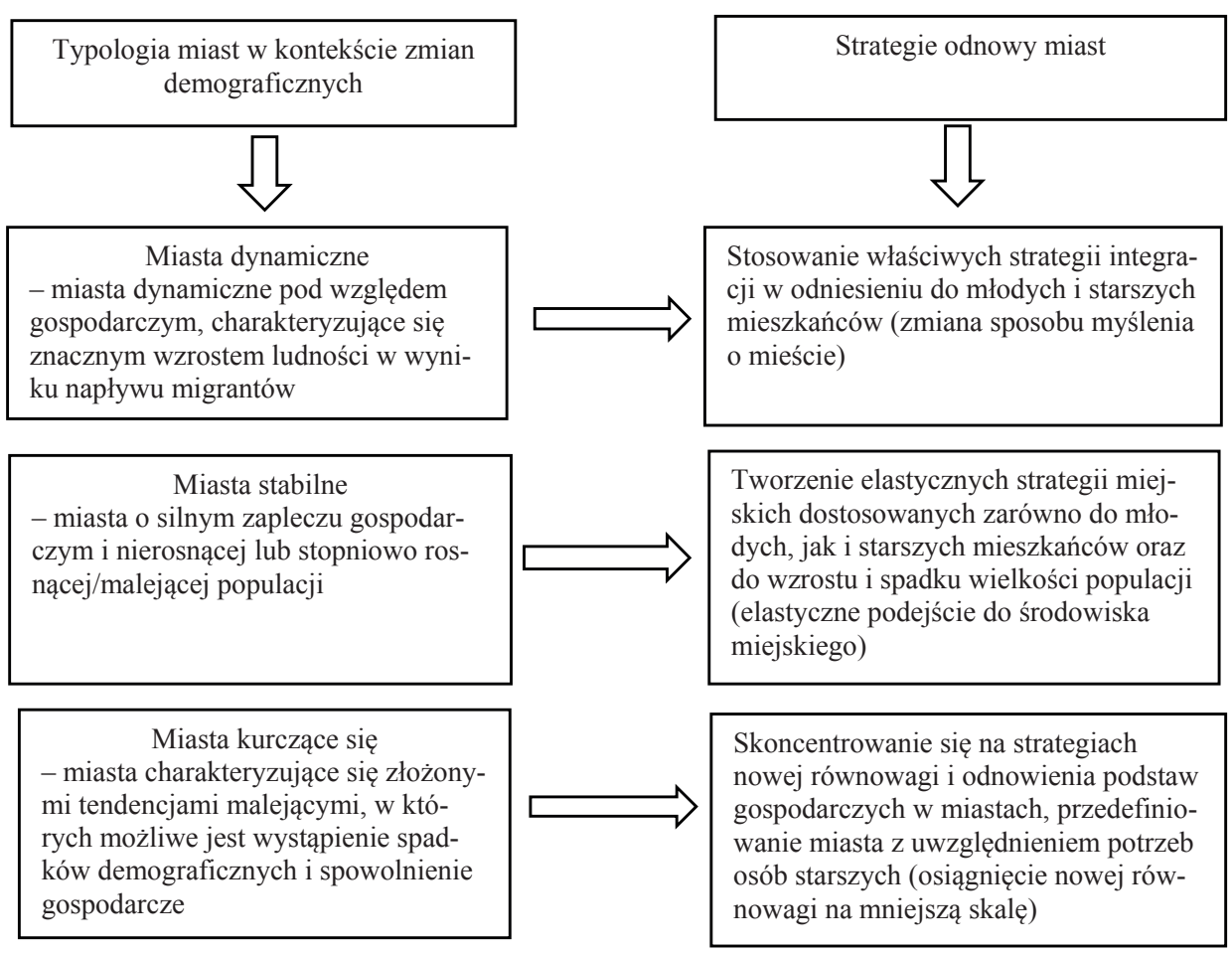

Ryc. 5. Strategie odnowy miast europejskich w kontekście zmian demograficznych

Źródło: opracowanie własne na podstawie: Komisja Europejska 2011, s. 17. 
Kluczowym wyzwaniem dla miast w XXI w. powinno być zatem wypracowanie nowych mechanizmów i strategii w zakresie przystosowania do nowych potrzeb, jakie stoją przed nimi.

Miasta kurczące się powinny być zatem stymulowane i promowane jako prężne ośrodki oferujące sprzyjające warunki do zamieszkania dla ludzi w każdym wieku. Miasta te wymagają osiągnięcia równowagi w każdej sferze życia, tj. demograficznej, społecznej, gospodarczej i przestrzennej, która otworzy przed nimi nowe wizje rozwojowe.

\section{Podsumowanie}

W krajach Unii Europejskiej wyodrębnia się trzy typy miast, tj.:

- dynamicznie rozwijające się pod względem gospodarczym - charakteryzujące się znacznym wzrostem ludności w wyniku napływu migrantów o zarówno wysokich, jak i niskich kwalifikacjach;

- o silnym zapleczu gospodarczym i nierosnącej lub stopniowo malejącej populacji;

- charakteryzujące się złożonymi tendencjami malejącymi, w tym obserwuje się zjawisko depopulacji i spowolnienie gospodarcze (Komisja Europejska 2011, s. 17).

W Polsce spośród miast liczących powyżej 100 tys. mieszkańców aż 30 należy do tej ostatniej grupy. Tendencje zmian ludnościowych w analizowanych miastach świadczą o ich niekorzystnej sytuacji demograficznej. W $2000 \mathrm{r}$. badane jednostki weszły w fazę wyludniania, powodowaną m.in. ubytkiem naturalnym i wzmożonymi migracjami. Depopulacja miast ulega ciągłemu pogłębieniu i według prognoz GUS w przyszłości zjawisko to będzie się nasilać.

Czynnikiem wpływającym na proces kurczenia się miast jest również niemożność znalezienia pracy. Zmniejszenie podaży zatrudnienia po 1989 r. nie zostało w pełni skompensowane przez nowo powstałe miejsca pracy. Pomimo poprawy sytuacji na rynku pracy stopa bezrobocia w większości tych miast nadal utrzymuje się na wysokim poziomie (powyżej 10\%).

W wyniku procesu kurczenia się miast zachodzą niekorzystne zmiany w przestrzeni. Ze względu na zmniejszającą się liczbę mieszkańców może nastąpić spadek zapotrzebowania na mieszkania i tereny mieszkaniowe w miastach. Spadek populacji przyczynia się również do wzrostu liczby pustostanów i terenów nieużytkowych. W efekcie spadku liczby ludności może nastąpić kurczenie się rynku nieruchomości. Na podstawie przeprowadzonej analizy można zauważyć, że największe problemy mieszkaniowe występują w miastach, gdzie utrzymuje się wysokie bezrobocie i występuje deformacja struktur demograficznych.

\section{Bibliografia}

Czarnecki B., 2011, Przejawy i konsekwencje depopulacji polskich miast. Zarys problemu, „Architecturae et Artibus" 4.

Główny Urząd Statystyczny, Bank Danych Lokalnych, www.stat.gov.pl. 
Haase A., 2013, No one-size-fits-all. O różnorodności kurczących się miast w Europie, [w:] Zarzadzanie rozwojem miast o zmniejszającej się liczbie mieszkańców (w kontekście perspektywy finansowej 2014-2020), Kancelaria Senatu, Warszawa.

Jaroszewska E., 2013, Akcja CiRES „Cities Regrowing Smaller” organizowana przez COST (European Cooperation in Science and Technology), [w:] Zarzadzanie rozwojem miast o zmniejszajacej się liczbie mieszkańców (w kontekście perspektywy finansowej 2014-2020), Kancelaria Senatu, Warszawa.

Jopek D., 2015, Przestrzenne aspekty procesu kurczenia się miast, [w:] Harańczyk A. (red.), Uwarunkowania $i$ konsekwencje procesu kurczenia się miast w Polsce, CeDeWu, Warszawa.

Kowalewski A., 2013, Wykład wprowadzajacy, [w:] Zarzadzanie rozwojem miast o zmniejszajacej się liczbie mieszkańców (w kontekście perspektywy finansowej 2014-2020), Kancelaria Senatu, Warszawa.

Kantor-Pietraga I., Krzysztofik R., Runge J., Spórna T., 2014, Problemy zarządzania miastem kurczacym się na przykładzie Bytomia, „Biuletyn KPZK PAN” z. 253.

Komisja Europejska, 2011, Miasta przyszłości. Wyzwania, wizje, perspektywy, Bruxelles.

Labus A., 2015, Strategie odnowy miast wobec depopulacji i starzenia się społeczeństwa w trzech skalach przestrzennych, http://forumprzestrzeniemiejskie.pl/images/Labus\%20A.,\%20Strategie\%20odnowy\%20 miast\%20wobec\%20depopulacji\%20i\%20starzenia\%20si\%C4\%99\%20spo\%C5\%82ecze\%C5\%84stwa.pdf (dostęp maj 2017).

Musiał-Malago' M., 2015, Przemiany gospodarcze w miastach Polski, [w:] Harańczyk A. (red.), Uwarunkowania i konsekwencje procesu kurczenia się miast w Polsce, CeDeWu, Warszawa.

Musiał-Malago' M., 2016, The process of urban shrinking in Poland, „Studia Miejskie” t. 24.

Musiał-Malago' M., 2017, Przestrzenne zróżnicowanie procesu kurczenia się miast w Polsce, „Prace Naukowe Uniwersytetu Ekonomicznego we Wrocławiu" nr 467.

Stryjakiewicz T., Jaroszewska E., Marcińczak S., Ogrodowczyk A., Rumpel P., Siwek T., Slach O., 2014, Wspótczesny kontekst i podstawy teoretyczno-metodologiczne analizy procesu kurczenia się miast, [w:] Stryjakiewicz T. (red.), Kurczenie się miast w Europie Środkowo-Wschodniej, Bogucki Wydawnictwo Naukowe, Poznań.

Wiechmann T., Walff M., 2014, Skala i przestrzenne zróżnicowanie procesu kurczenia się miast w Europie na przełomie XX i XXI wieku, [w:] Stryjakiewicz T. (red.), Kurczenie się miast w Europie Środkowo-Wschodniej, Bogucki Wydawnictwo Naukowe, Poznań.

Zborowski A., Soja M., Łobodziński A., 2012, Population trends in Polish cities - stagnation, depopulation or shrinkage?, „Prace Geograficzne” 130. 